\title{
Os Estados Unidos e a Inglaterra vistos pelo cinema soviético do stalinismo tardio.
}

\section{The United States and England seen by Late Stalinism Soviet cinema.}

Moisés Wagner Franciscon*

Resumo: O sistema soviético sofreu uma série de reformas no pós-guerra que, se não deram origem ao esperado regime mais liberal, amenizou algumas de suas características (como a eliminação física) e acentuou outras (como a eficácia da censura). Externamente, a Primeira Guerra Fria exigia uma luta cultural travada em iguais condições com aquela criada pelos impérios rivais anglo-americanos. O cinema assumiria importantes funções de contrapropaganda interna e externa. Os vilões estrangeiros genéricos dos anos 1930 dão lugar a personagens claramente caracterizados ou anunciados como britânicos e estadunidenses. A sócio-história cinematográfica de Marc Ferro permite demonstrar que, apesar da existência residual da crítica marxista-leninista, impõe-se uma imagem invertida da própria propaganda antissoviética das duas democracias liberais. Assim, para o cinema soviético do período (1945-53), os bêbados, autoritários, improdutivos, caóticos economicamente, presas e agentes da censura são os anglo-americanos. Palavras-chave: Cinema. Stalinismo tardio. Guerra Fria. Anglo-americanos.

Abstract: The Soviet system underwent a series of postwar reforms that, if not given rise to the expected more liberal regime, softened some of its characteristics (such as physical elimination) and accentuated others (such as the effectiveness of censorship). Externally, the First Cold War required a cultural struggle waged on equal terms with that created by rival Anglo-American empires. The cinema would assume important functions of internal and external counter-propaganda. The generic foreign villains of the 1930s give way to characters clearly characterized or heralded as British and Americans. Marc Ferro's cinematic socio-history shows that, despite the residual existence of Marxist-Leninist criticism, an inverted image of the anti-Soviet propaganda of the two liberal democracies is necessary. Thus, for Soviet cinema of the period (1945-53), the

\footnotetext{
* Graduado, especialista e mestre em História pela UEM, doutor em História pela UFPR.
} 
drunks, authoritarian, unproductive, economically chaotic, prey, and agents of censorship are the Anglo-Americans.

Keywords: Movie theater. Late Stalinism. Cold War. Anglo-Americans.

Até a Segunda Guerra a personificação do capitalismo e imperialismo nos filmes e animações soviéticos cabia à Inglaterra. Os americanos apareceram em filmes que salientavam a desigualdade social e o racismo. Com o mundo bipolar emergido com a Guerra Fria e o crescente colapso do Império Britânico, os americanos tomam rapidamente o papel dos ingleses, sem que estes desapareçam por completo. No entanto, tornam-se coadjuvantes. Roosevelt, inicialmente representado positivamente, ao menos até 1949, passa a dividir com Churchill a imagem de traição. Outros filmes mostram americanos, através de espiões, cientistas malvados, políticos e diplomatas ardilosos, imprensa falseadora ou inversora da realidade, de uma casta de senhores que detém e distribuem/negam privilégios econômicos, e um sistema político-judiciário tirânico, ameaçando e controlando pequenas nações indefesas, cabendo aos soviéticos e seus aliados bloqueá-los em suas ações.

O objeto de análise é constituído por películas que, em algum momento ou tematicamente, representam americanos e britânicos, produzidas entre 194553, anos que compreendem a última fase do stalinismo, dito tardio (FÜRST, 2006; WARD, 2004), preocupado com sua reafirmação do monólito políticoideológico-cultural, a reconstrução acelerada do parque industrial e agrícola do país e a modernização e ampliação de seu poderio militar dentro de suas fronteiras; e fora delas, com a manutenção das conquistas territoriais, diplomáticas e políticas ${ }^{1}$ que custaram tão caro ao país, quase ao ponto da ruptura e derrota (WERTH, 1966), que estavam sob constante e crescente pressão por parte do imperialismo inglês e americano, ao mesmo tempo em que, elaborando seu próprio imperialismo (CHOMSKY, 1996), ampliavam vitoriosamente ou buscavam expandir sua influência sobre o novo campo socialista em áreas que nunca foram liberadas do Eixo pelo Exército Vermelho (a maior parte da China com a exceção da Manchúria libertada em agosto-setembro de 1945, as revoltas e guerras civis no Vietnam do Norte, Malásia, Grécia, Pérsia, etc.), ou manter seu

${ }^{1}$ Lewin (2007) chega a afirmar que o regime se fascistizou, com a transferência das alavancas do poder do partido para o Estado, sob a batuta do ditador. 
capital político alto entre importantes parcelas da população votante de países como Itália e França. Foram selecionados filmes feitos dentro do recorte cronológico supracitado cuja temática principal se ocupasse de maneira primordial ou como trama secundária das representações do inimigo anglosaxônico, fornecessem curtas passagens de interesse sobre estas, alcançaram bilheterias expressivas ou que foram produzidos por cineastas reconhecidamente importantes para os soviéticos ou críticos ocidentais. Portanto, vários gêneros são abarcados: espionagem, drama, histórico, guerra, aventura, comédia, docuficção, adaptação. Assim, Sekretnaya missiya [Missão secreta], de Mikhail Romm, Padenie Berlina [A queda de Berlim], de Mikheil Chiaureli, Proshchay, Amerika! [Adeus, América!], de Aleksandr Dovjenko e sua esposa Julia Solntseva, Velikiy perelom [A grande virada], de Fridrikh Ermler, e Vstrecha na Elbe [Encontro no Elba], de Grigori Aleksandrov, constituirão a matéria-prima essencial, porém não única. Ao todo foram utilizadas 19 películas. Russkiy vopros [Questão russa], de Mikhail Romm, obtém posição principal em decorrência de seu tratamento do regime americano segundo uma crítica profunda - segundo a ótica política dos mandatários do Kremlin, e de costumes, presente no nacionalismo russo socialmente afluente a partir da década de 1930, e muito presente no pós-guerra, com o sentimento advindo da vitória sobre a Alemanha nazista, senhora dos recursos humanos e industriais de quase toda a Europa. Uma mulher que abandona o marido por dinheiro seria algo abjeto numa cultura que exigia que a mulher esperasse pelo retorno do marido, mesmo no quadro dos desaparecidos durante a Grande Guerra Patriótica (ALEKSIÉVITCH, 2016).

A sócio-história cinematográfica é uma ferramenta preciosa para a análise desses filmes. Ao postular que é possível passar do visível para o invisível, de mensagens claras e anunciadas para as sutis, subjetivas, subentendidas para aquelas pessoas evolvidas com a produção e consumo, de maneira consciente ou não, planejada ou não-intencional. O que permite lançar luz especialmente sobre filmes históricos ambientados em outro período que não a campanha conjunta contra o Eixo e o período contemporâneo do surgimento da Guerra Fria e definição do status político e socioeconômico de boa parte do continente europeu, dividido entre os impérios rivais. Filmes sobre o passado militar da Rússia czarista ou da luta de independência dos novos aliados-satélites do Leste Europeu, mais do que a história do que de fato sucedeu nas respectivas épocas 
representadas, tratavam das novas cadeias de lealdade, da nova organização social, do novo lugar no mundo ocupado por esses países.

Quando diretores com trabalhos consagrados, como Alexander Dovjenko ou Mikhail Kalatozov, precisam mudar substancialmente seu trabalho, torna-se difícil defender a abordagem de Rosenstone (2015), que perceberia tais transformações como necessidade artística de seus produtores, e não influência ou coação político-econômica. Tampouco concordamos com Sheila Schvarzman (2013, p.8) e Eduardo Morettin (2003, p.8; 14), que afirmam que a teoria sóciohistórica cinematográfica de Marc Ferro se aplica apenas aos filmes produzidos sob regime totalitário. O autor francês, pelo contrário, deixa claro que sua metodologia abarca igualmente regimes capitalistas ou socialistas, democráticos ou autoritários (FERRO, 1992, p.13-14) - quase nunca utilizando a expressão "totalitarismo". Uma de suas obras mais recentes, reunindo uma série de artigos sobre o cinema, possui apenas uma fração dedicada ao stalinismo, fascismos alemão, italiano ou francês (FERRO, 2008). Posição importante, uma vez que existem mais semelhanças entre filmes que estereotipam o inimigo de ambos os lados da Cortina de Ferro do que diferenças, e que seriam inconcebíveis ou inexplicáveis pelo modelo de Morettin e Schvarzman.

A composição da imagem do inimigo dentro de uma trama de tragédia, sátira ou comédia poderia igualmente remeter a Hayden White (1995). No entanto, as gradativas mudanças na representação do oponente no quadro da Guerra Fria parecem se encaixar melhor com a perspectiva de Ferro, que prevê o cinema como produto social, formulado ao sabor das circunstâncias ao seu redor. Por mais que tais filmes estejam repletos de propaganda, nem sempre sua leitura é unidirecional, totalmente dentro das expectativas do regime. A ambiguidade proporcionada pela linguagem cinematográfica, segundo Ferro, pode ser consciente ou não, e pode ser lida de diferentes maneiras por diferentes plateias em diferentes épocas. Quando um diretor que se encontra à mercê de uma tirania produz material anfibológico passa a correr riscos de ser bem ou mal interpretado. Tal comportamento pode ser explicado pela busca de reconhecimento entre seus pares, dentro da classe artística, cujo capital gira em torno da liberdade artística (BOURDIEU, 1996) - diante do passado das artes russas, em especial a literatura, também a liberdade de crítica social ou sua feitura disfarçada. O jogo de interesses entre o Kremlin, a indústria do cinema e seus 
diretores, os cineastas e atores, e o público pagante, que mantinha a máquina do cinema soviético, não eram mutuamente excludentes. Procurou-se por diversas formas de acomodação, que passavam do engajamento voluntário ao carreirismo $^{2}$, à adesão parcial ou a crítica sútil - nessa fase, em geral fadada ao fracasso.

Para os cineastas, esse período foi o de mais intensa repressão e autocensura. Se as prisões de pessoal ligado à indústria do cinema não foram tão extensas quanto as ocorridas durante as purgas da década de 1930, as agências de controle e censura estavam mais atuantes e ágeis, os diretores de estúdios e pessoal da produção mais ciosos das consequências para suas próprias carreiras, e vidas - como o caso do teatrólogo Solomon Mikhoels, morto num suspeito acidente automobilístico em 1948 (CONQUEST, 2000, p.101). A representação do inimigo na nascente Guerra Fria era um dos campos do cinema mais controlados pelo Estado. Encomendas eram feitas, listas temáticas impostas, diretrizes políticas emanadas. Contudo, se o espaço para a ambiguidade diminuiu, aumentou a dedicação dos cineastas a filmes não comissionados, produzidos sem ordens específicas, com os recursos capitados pelos estúdios com a venda de ingressos. Diretores que não aceitavam trabalhar para a propaganda ou inseri-la em seu trabalho, passaram simplesmente a rodar musicais (como na América no mesmo período3), biografias de cientistas, compositores, literatos e

\footnotetext{
2 Meney (1984, p.1986) cita algumas comodidades que a adesão poderia proporcionar. O cineasta Alexandre Lomakov comprou um Mercedes Benz 340 SKL, raríssimo, capturado dos alemães no Cáucaso. $\mathrm{O}$ correspondente francês também relata que carros importados pelo pessoal ocidental a serviço na URSS eram negociados no mercado negro para soviéticos com alto poder aquisitivo - o que era o caso de cineastas bem-sucedidos nas bilheterias da União Soviética -, apesar de ser uma prática oficialmente proibida. Se o regime poderia fechar os olhos para o comportamento heterodoxo de seus adeptos, cineastas dissidentes enfrentavam o esquadrinhamento de suas vidas privadas pelo serviço secreto e polícia em busca de crimes comuns ou políticos que os pusessem fora de circulação. Paradjanov acabou detido por alguns anos em prisão comum e psiquiátrica por contrabandear ícones - patrimônio cultural soviético - e por homossexualismo e estupro de um menor de idade (ROLLBERG, 2009, p.17; 157; 519). A realidade da Era Brejnev (e do caso positivo de Lomakov ou negativo de Sergei Paradjanov), sob esse ponto, não era distinta da de Stalin. As punições é que mantinham diferenças abissais. A diretora Margarita Barskaya foi presa em 1937 e enviada para o Gulag, onde morreu, provavelmente em virtude da rigidez do regime de trabalho, alimentação e habitação, em 1938 (KENEZ, 2001, p.139).

3 A Alemanha nazi, como a URSS, apostava na cooptação de estúdios e diretores com recursos financeiros provenientes de encomendas estatais (na Alemanha Staatsauftragsfilms) e de prêmios distribuídos pelo governo segundo seus critérios (PEREIRA, 2012, p.649). A cooptação nos EUA seguiu as necessidades impostas pelo Código Hayes de censura, à comunhão de interesses entre o financiamento privado e o governo americano, e a atuação do sistema de estúdio e de produtores no controle da feitura do filme, tornando-se indireta (PEREIRA, 2012, p.172-190; 648-649). Outros autores (SILVA, LEÃO, LAPSKY, 2015) lembram, no cenário da Guerra Fria, uma interferência direta das agências do governo na indústria do cinema, por exemplo, atuando em sua distribuição na Europa ocupada.
} 
exploradores, e o gênero de fantasia ou conto de fadas baseado no rico folclore eslavo (YOUNGBLOOD, 2007, p.88). Essa fuga da realidade não era uma possibilidade para todos, como o caso Dovjenko deixou claro. Havia poucas possibilidades de encomendas, com a renda popular contraída, o Estado preocupado com a reconstrução de boa parte de seu parque produtivo industrial e agrícola e a modernização de seu poderio bélico, com boa parte das salas de cinema reduzidas a cinzas e a indústria cinematográfica dispersa pelas repúblicas após o avanço alemão de 1941 rumo à Moscou. Nem por isso os cineastas transformaram-se em burocratas da propaganda, como aponta Pipes (2017, p.332) já para os experimentalistas da década de 1920, ou que sua entrega às diretrizes do partido os transformassem em propagandistas, como Overy (2009) acusa Eisenstein. Alguns filmes anti-anglo-saxônicos desse período mantiveram um certo padrão artístico, ao menos como conceituado por Bordwell e Thompson (2013) e Youngblood (2007): eles cumpriam satisfatoriamente bem seu papel legitimador como entretenimento. Alguns, no entanto, eram mais propagandistas e menos inspirados técnica e artisticamente que outros.

Já em 1946 (SILVA, LEÃO, LAPSKY, 2015) o regime passou a emanar novas diretrizes para a produção de propaganda. A pedido dos aliados ocidentais, a Terceira Internacional Comunista fora fechada em 1943. Agora percebia-se que o mundo entraria num novo jogo de soma zero, no qual a expansão de um império dar-se-ia apenas com a retração de outro. Apesar dos acordos de Yalta, ações americanas como o apoio às guerrilhas anticomunistas no Báltico e Cárpatos e a pressão sobre a Polônia e o Irã confirmavam para o Kremlin que os antigos aliados não estavam dispostos a dividir com os soviéticos suas novas áreas de influência (como a Líbia italiana, agora repartida entre Inglaterra e França), mas estavam ansiosos para obter o controle sobre a zona de ocupação da URSS. A decisão do Partido Trabalhista britânico em honrar os compromissos de Churchill com o subcontinente indiano em 1947 evidenciava que o Império Britânico, sem sua joia, entraria em decadência. O nascente movimento de descolonização proporcionava a oportunidade para os soviéticos eliminarem de vez o cordão sanitário, estabelecendo relações comerciais ou zonas de influência nos Estados emergentes. Nesse quadro se insere a jdanovchina. A doutrina do então presidente (1946-47) e segundo secretário do Partido Comunista Andrei Jdanov era apropriada para sua concepção de mundo dividido em dois campos 
no pós-guerra, segundo a qual cada lado tentaria sob todas as formas obter espaço sobre o outro. O combate artístico e cultural seria tão importante quanto a corrida armamentista. Falhar nessa área seria expor o espirito popular aos projetos inimigos. Mesmo a estética oficial do realismo socialista sofreu mudanças ${ }^{4}$. Em 1947 receberia o nome de Doutrina dos dois campos (VOLKOGONOV, 2004, p.607). Durante a guerra, a aproximação política com os aliados ocidentais liberou os segmentos ocidentalizantes a reintroduzir sua música e cultura, banidas durante a década de 1930. A propaganda anti-anglo-saxônica também visava atingir esses grupos, vistos como pouco confiáveis, eliminar sua influência e disseminação social (e, portanto, as influências ocidentais) e reconduzi-los às diretrizes partidárias.

Uma [...] interpretação, mais frutífera, diz respeito às campanhas culturais e científicas como uma tentativa de "colocar o gênio de volta na garrafa" e recuperar o controle sobre a sociedade soviética depois da guerra. O pró-ocidentismo da intelligentsia é o "gênio" mais comumente citado a ser combatido. No entanto, outros estudiosos sugeriram que, pelo menos a partir de 1948-9, as campanhas foram direcionadas a um público muito mais amplo. O grande volume de esforço investido na campanha michurinista [outro nome para o lysenkoismo, já que Lysenko considerava-se continuador da obra do biólogo Ivan Michurin] ou o ataque ao cosmopolitismo indica que eles pretendiam moldar o pensamento e as ações da comunidade soviética em geral (JOHNSTON, 2011, p.178-179. Tradução livre).

Johnston aponta que os principais episódios criados pela jdanovichina e outras políticas de fechamento do regime no pós-guerra ocorreram concomitantemente com crises políticas com os ex-aliados, o que reforçaria a campanha do governo contra a influência externa e também geraria justificação para suas ações diante dos novos adversários.

A carta fechada do Comitê Central sobre o caso K.R. [no qual cientistas soviéticos foram acusados de transmitir segredos para os americanos, servindo de justificativa para o estancamento da

\footnotetext{
4 "Também a política cultural do último período do stalinismo - que será chamada doravante de "zdhanovismo" (jdanovitchina) - apresenta-se como puramente negativa e repressiva, sem nenhuma possibilidade de iniciativa ideológica; e, para a cultura russa, aqueles anos - que se seguirão a uma duríssima guerra vencida graças aos sacrifícios e aos heroísmos de todo o país constituem uma página negra, que não tem igual em toda a sua história. Por isso, é justificado falar de uma evolução (regressiva) do "realismo socialista" para o "zdhanovismo": o "realismo socialista", assumido aqui como fórmula político-literária e como símbolo de toda uma fase da cultua soviética, continua a ser a doutrina oficial de todo o período staliniano, bem como do pósstaliniano, mas cairíamos numa simplificação se [...] não víssemos e analisássemos a diferença, e não só a indubitável continuidade, entre os anos 30 e 40" (HOBSBAWM, 1987, p.153-154).
} 
troca de informações e tecnologia - inclusive revistas cientificas - entre ambos e a presença de membros do partido junto ao corpo científico] circulou no dia anterior ao encontro vital de junho de 1947 do Conselho de Ministros das Relações Exteriores e a vitória de Lysenko sobre seus rivais geneticistas ocorreu contra o pano de fundo do Bloqueio de Berlim em meados de 1948. O ataque à música formalista também ocorreu no exato momento em que as linhas de batalha estavam endurecendo durante o golpe tcheco. Da mesma forma, o ataque de janeiro a abril de 1949 ao cosmopolitismo mapeou de perto as discussões no Ocidente sobre a construção da OTAN. Os tons anti-judaicos da campanha anti-cosmopolita também refletiram esse contexto global. Os judeus soviéticos forneceram, até certo ponto, uma metáfora crua para o capitalismo global: sua suposta dominação do comércio soviético fez deles um arquétipo doméstico do inimigo externo (JOHNSTON, 2011, p.179).

Se em alguns tópicos a propaganda soviética no cinema fora original, como a defesa do internacionalismo ou a exploração do homem pelo homem dentro do modelo capitalista, em outros apenas inverteu imagens que o próprio cinema anglo-americano fazia da população russa e de seu sistema político. Em alguns casos, até mesmo o roteiro de filmes hollywoodianos anticomunistas e antissoviéticos é aproveitado para produzir filmes em Moscou ou Kiev. Antigas diferenças e discursos, surgidos ainda no embate dos impérios neocoloniais em áreas de fronteira, como a Questão Oriental em torno da Turquia ou da luta pela supremacia no coração da Ásia, são reaproveitados e desenvolvidos para obter nova (ou velha) significação diante da Primeira Guerra Fria5.

\section{Anglo-americanos como alcoólatras}

É difícil imaginar uma representação mais recorrente da população russa no cinema ocidental do que a do embriagado por garrafas de vodka, como em $O$ inimigo $X$ [Comrade X], 1940, de King Vidor, Ninotchka, 1939, de Ernst Lubitsch ou uma das primeiras grandes produções ambientadas na Rússia soviética, O barqueiro do Volga [The Volga boatman], 1926, de Cecil B. DeMille.

Em Proshchay, Ameryka! [Adeus, Améria!], 1951, de Dovjenko, Charles Winchell [Janis Osis], médico da embaixada americana, entende o sistema capitalista e o modelo americano, os segue por sobrevivência, e pode se mostrar

\footnotetext{
5 Segundo Hallyday (1989) a Guerra Fria pode ser dividida em quatro fases: Primeira Guerra Fria (1946-1953), Período de Antagonismo Oscilatório (1953-1969), Détente (1969-1979) e a Segunda Guerra Fria (após 1979).
} 
amigo o suficiente da protagonista Anna Bedford [Lilia Gritsenko] para forjar fotos antissoviéticas ao gosto do embaixador - e que a assistente fora incapaz de produzir por amor à verdade, eximindo-a de problemas. Se julga mais canalha do que o conselheiro da embaixada, Marrow [Alexander Polinsky], pois este faz carreira com as mentiras sobre a URSS, enquanto ele apenas pode encontrar conforto no álcool, sem oportunidades possíveis (o que, mais uma vez, seria um mote da propaganda americana contra os embriagados soviéticos). Os personagens com comportamento de gangsteres - auxiliares e militares, não bebem menos. O técnico de comunicações e da rede secreta de microfones e seu ajudante aparecem diversas vezes prostrados pela bebida, sobre mesas ou macas. Em Sekretnaya missiya [Missão secreta], 1950, de Michael Romm, insinuam-se as bebedeiras de Churchill [Mikhail Vysotsky] em seu gabinete de guerra - uma grande garrafa de whisky esvaziada pela metade. Apenas a menção dos avanços do Exército Vermelho e de Stalin sobre os nazistas pode impedir o primeiroministro de encher seu copo. Em Russkiy vopros [Questão russa], 1947, de Mikhail Romm, o repórter Hardy [Boris Poslavsky], que se confessa para o protagonista Harry Smith [Vsevolod Aksyonov], encontra no gim, e, com o pagamento de Smith, no whisky, coragem para criticar sua vida de dificuldades financeiras decorrentes dos parcos pagamentos por matérias policiais e sensacionalistas nos tabloides e da falta de ética dos jornalistas americanos, como ele reféns do sistema e da necessidade de manter sua família. Em Vstrecha na Elbe [Encontro no Elba], 1949, de Grigori Aleksandrov, a bebida é recorrente no gabinete dos ocupantes americanos em Berlim Ocidental. E a beberagem é um dos estopins dos conflitos étnicos e desordens de todo gênero num bar para os simples soldados. Em Zastava $v$ gorakh [Posto avançado nas montanhas], 1953, de Konstantin Yudin, o falso arqueólogo americano, na realidade um espião, se nega a beber o leite dos bandidos basmachis, tirando do bolso uma garrafa. Em Serebristaya pyl [Pó de prata], 1953, de Pavel Armand e Abram Room, o xerife procura arrancar informação da garçonete com bebida; os generais também bebem, porém não whisky, mas sim licor. Todas as reuniões de negócios são regadas a álcool. Como o encontro Göring-Bedstone em Padenie Berlina.

A associação do inimigo capitalista anglo-americano com a bebedeira não era recente ou limitada ao stalinismo tardio. Ainda durante a NEP, o diretor Aleksandr Dovjenko rodara o filme de espionagem Sumka dipkuryeva [Mala 
diplomática], de 1927. Ao contrário das produções surgidas após a centralização e burocratização da indústria do cinema, que demoravam em média dois anos para ficarem prontas e serem liberadas ao público soviético (MILLER, 2010), o cinema da década de 1920 era muito mais ágil e produtivo. Nesse mesmo ano um incidente diplomático, envolvendo sindicatos trabalhistas, alegado dinheiro soviético e publicidade para o famoso e influente ministro Lord Curzon (já uma figura de relevo na guerra entre Polônia e URSS em 1920 pela posse dos territórios da Bielorrússia e Ucrânia), levou ao embargo britânico dos cereais soviéticos. A ameaça de novo isolamento internacional aumentou a necessidade do regime alterar seu sistema econômico misto e a investir numa rápida industrialização e autarquização. Assim, os vilões desse filme são os britânicos. $O$ comandante do navio inglês que transporta a mala diplomática soviética roubada por espiões britânicos é pintado como um alcoólatra que não deixaria muito a desejar ao capitão Archibald Haddock.

Alcoolismo e beberagem, mais do que uma tentativa de retratar um povo ou cultura, ou uma reação natural ao clima, é uma imagem poderosa para desacreditar e desmoralizar o inimigo. Filmes conservadores sobre a Revolução Francesa, por exemplo, repetem tal imagem 6 .

\section{Falsos aliados, incapacidade dos anglo-americanos de serem sinceros ou confiáveis}

O combatente anglo-saxônico, apesar de todo o aparato bélico, seria muito inferior ao soviético, e mesmo ao alemão. A verdadeira ameaça militar ocidental é a nuclear, vetorizada por bombardeiros estratégicos e marinha - daí a necessidade do arroxo nas condições de vida do pós-guerra para financiar a corrida armamentista. Os dirigentes políticos ex-aliados sempre teriam percebido os nazistas como aliados potenciais, e seus dirigentes econômicos, fregueses importantes durante a guerra. Seus diplomatas perceberiam um erro de alianças no conflito. O povo soviético e seu modelo sempre teriam sido percebidos como os verdadeiros inimigos a serem combatidos, e não o nazismo.

\footnotetext{
${ }^{6}$ Há uma vertente cinematográfica que enfoca a situação popular e as causas da Revolução, mas também uma que procura enfatizar suas tragédias e uma oposição elite civilizada versus populacho (FERRO, 2008, p.38-39).
} 
Sekretnaya missiya é um dos únicos filmes soviéticos a representar tropas anglo-americanas em combate, e não em desembarques e movimentações que mais parecem uma parada militar. Tais tropas, no entanto, estão sendo enxotadas pelo avanço alemão nas Ardenas, em dezembro de 1944. Omar Bradley, Dwight Eisenhower e Bernard Montgomery, apesar das ordens ameaçadoras e esbravejadas, não conseguem conter a debandada frente ao inimigo. Os aliados ocidentais conscientizam-se de que seu poder na Europa está ameaçado. Reconhecem ser impossível para eles derrotarem e conquistarem território nazista, enquanto os soviéticos avançam rapidamente. Resta a Churchill - que para horror do personagem real mantém um busto de Napoleão sobre a mesa, e não o de Horatio Nelson, do duque de Wellington ou de seu ancestral John Churchill, 1. ${ }^{\circ}$ Duque de Marlborough (o primeiro é muito mais significativo como imagem do poder e da invasão para o público soviético do que os demais) -, implorar auxílio a Stalin, em 5 de janeiro, para adiantar sua ofensiva planejada sobre o Vístula-Oder, para o dia 12. Do contrário, suas tropas seriam lançadas num novo Dunquerque. No dia 10 de janeiro, munidos de passaportes portugueses e em avião português, um senador americano, Allan [Nikolai Komissarov] e um agente da CIA, Garvey [Sergey Vecheslov] partem para Berlim, para encontros indiretos com o novo chefe do Reichssicherheitshauptamt, Gabinete Central de Segurança do Reich, sucessor político da Abwehr, o serviço de informação do exército alemão, Walter Schellenberg [Alexander Pelevin], que assumiu após o fuzilamento do almirante Wilhelm Canaris por traição, em 1944. Schellenberg atua conjuntamente com Himmler [Piotr Berezov] e Bormann [Vladimir Belokurov], que pretendem salvar o Reich e o capitalismo industrial alemão apesar da loucura de Hitler [Vladimir Saveliev], insensível a qualquer tentativa de acordo. As negociações iniciais promovem uma virtual rendição alemã no ocidente: tropas alemães marcham como num desfile para se entregar aos anglo-americanos. Estes utilizam do mesmo comportamento para atingir as posições alemães. Ambas as tropas se cumprimentam com suas bandeiras e encontros entre oficiais. No entanto, os soviéticos, enfrentando pesada resistência, continuavam avançando mais rápido do que os aliados ocidentais, comprometidos com seus passeios. A Europa Central encontrava-se além de seu alcance. Alemães, americanos e ingleses planejam uma frente conjunta pela civilização: com a saída unilateral da guerra dos aliados ocidentais, a Alemanha 
ficaria livre para combater apenas a URSS. Inglaterra e Estados Unidos manteriam sua influência sobre a Europa, inclusive por meio de acordos comerciais entre suas burguesias e a alemã. Ocorrem negociações para a venda de metais e recursos essenciais e em falta para manter o país na guerra. Os capitalistas alemães, como os armamentistas Krupp, reúnem-se para tratar dos investimentos e a oferta ocidental de níquel, volfrâmio-tungstênio, cromo, manganês e borracha. Essa aliança informal que constituiria a "Terceira frente" contra a URSS é frustrada pela agente Martha Shirke, na realidade Masha Glukhova [Elena Kuzmina], que se faz passar por motorista e estafeta da SS e revela aos quadros fanáticos da Gestapo e SS os encontros indiretos de Himmler e os anglo-americanos. O filme possuiu um fundo de verdade. As forças da Alemanha depuseram suas armas na Itália, dias antes do fim da guerra, após encontros germano-americanos em Berna, na Operação Sunrise, ou o incidente de Berna, durante os meses de fevereiro-março, entre o general da Waffen-SS Karl Wolff e o agente americano Allen Dulles (futuro diretor da CIA e irmão de John Foster Dulles, secretário de Estado), com o conhecimento direto de Churchill (GILBERT, 1986, p.65).

Em Proshchay, Ameryka!, enquanto a NBC divulga nota da ocupação soviética de Berlim, precedida por pesado bombardeio, insinuando a agressividade soviética, a canção de fundo é produzida por soldados americanos: estes, como de costume, não combatem. O trabalho da vitória é soviético. Os anglo-americanos pretendem reservar para si o monopólio do usufruto dos despojos. Embaixadores americanos e seus conselheiros britânicos passam o período das comemorações soviéticas do Dia da Vitória se recriminando sobre a culpa pelo fim da guerra e de seus resultados funestos para ambos os imperialismos, que perderam influência sobre metade da Europa - se a estratégia falha de Churchill ou os prognósticos errados dos americanos que acreditaram que o Estado soviético sucumbiria aos nazistas. Como estes, precisam salvar a civilização do bolchevismo. No entanto, não parece ser uma possibilidade para os ingleses: um dos diplomatas americanos faz o prognóstico do fim do império britânico (auspício interessante. Apesar de sua fraqueza e de várias revoltas, até 1951 os britânicos perderam apenas o subcontinente indiano e a Palestina, além das colônias italianas na África, confiscadas ao fim da guerra) e a transformação da ilha no $49^{\circ}$ estado americano, o que gera um engalfinhamento geral. Apesar 
de ser o dia da vitória, trabalham sobre o mapa na parede que possuiu as fronteiras de 1946. Mas todos concordam em um culpado: "Maldito seja este cabo alemão! Perder uma guerra de tal maneira!”.

Em Vstrecha na Elbe o tema da vitória isolada soviética retorna. Os americanos não combatem. Apenas aparecem para tomar sua porção da Alemanha e de Berlim, conquistadas com sangue russo. Um soldado soviético diz: "que interessante. Ver a segunda frente no último dia da guerra". Os nazistas procuram atingir o lado americano, certos de que não serão presos. Em Padenie berlina além de não participar ativamente do confronto, insistem que, ao contrário dos prisioneiros civis, como prisioneiros de guerra não podem ser simplesmente fuzilados pelos nazistas no campo de extermínio. Os civis apresentam mais coragem, dignidade e ordem diante da morte do que as tropas anglo-americanas. Como em Sekretnaya missiya, o alto escalão nazista se encontra com a burguesia ocidental para derrotarem o inimigo comum, através do fornecimento de matérias-primas. Göring (Jan Werich, ator tchecoslovaco), sob ordens diretas de Hitler (Vladimir Savelev) se encontra com o capitalista inglês Bedstone (K. Roden), numa trama envolvendo a Suécia, Espanha e Turquia7. Os bombardeios aéreos anglo-americanos, que destruíram cidades inteiras por toda a Europa ocupada, de Carentan a Ploesti, de Milão a Hamburgo, seriam apenas "fumaça e clarões".

Nem sempre foi esta a imagem dos aliados. O filme Velikiy perelom [A grande virada], de Fridrikh Ermler, estreou em 1945, foi rodado durante a guerra e exibido antes das tensões do pós-guerra. Faz-se menção negativa à demora da abertura da segunda frente, mas também as vitórias anglo-americanas no Norte da África, além de aparecer muito equipamento do programa de Lend-lease, como tanques Sherman, jipes Willys, caminhões Studebaker e metralhadoras Browning.

\footnotetext{
7 Roland (2018, p.198) aponta que o tungstênio era fornecido pela Espanha e o cromo pela Turquia. A Istorria de 1960 (p.32) fala de monopólios americanos que investiram na produção de tungstênio na Alemanha nazista, porém antes da guerra. Seu terceiro volume $(1961, p .8)$ cita as empresas alemãs que o produziam, além de outras sediadas em países cativos da Europa Ocidental. A Suécia era fornecedora de minério de ferro. O que o cinema stalinista faz é misturar e comprimir datas e a cronologia dos eventos, gerando credibilidade em sua mensagem de conluio das democracias liberais com os fascismos.
} 


\section{As massas}

Se dividem em dois: "lumpemproletariado", agressivo, covarde, bêbado, rapace, virtualmente conservador e impermeável à “verdade”, uma vez que peçachave em seu sistema, e o proletariado, urbano ou rural - podendo ser chamado de camponês ou fazendeiro, que mesmo mergulhados na ideologia falsa do capitalismo, estariam propensos a ouvir e aceitar ideias progressistas ou mesmo comunistas.

Em Proshchay, Ameryka!, da mesma forma que filmes americanos exibem a rapina soviética, Dovjenko põe em cena militares americanos negociando bens surrupiados dos museus europeus. Não há comoção pela importância histórica e cultural das peças, apenas o interesse por seu valor de venda. O mesmo ocorre no castelo do general americano McDermot [Vladimir Vladislav] em Vstrecha na Elbe, com a diferença de que os americanos afirmam claramente que impõe os preços para a aquisição das obras. A desconsideração pela cultura e arte não seriam estranhas à retórica conservadora ocidental antissoviética. Trata-se de uma horda de destruídos da arte e cultura. Mais uma vez Dovjenko se mostra dúbio. Os americanos carregados de tecidos caros, taças e louças, e especialmente relógios, não seriam estranhos ao público soviético. Em Berlim, mais de dois milhões de soviéticos lutaram, na Prússia Oriental, 1,6 milhões (GLANTZ; HOUSE, 1995, p.300). Beevor (2015) dá indicativos da extensão da pilhagem praticada pelos soviéticos na região. Esses bens foram enviados pelos soldados para seus familiares na URSS e vieram a equipar a casa de altos oficiais. O saque foi geral - basta lembrar que a Mona lisa acabou em mãos de um coronel americano.

Em Vstrecha na Elbe o oficialato (os generais são verdadeiros burgueses da indústria, finanças e investimentos) e o lumpemproletariado saqueiam a Alemanha, de suas obras de arte as suas florestas, além, é claro, de suas mulheres - selecionadas e "compradas" como quadros, obrigadas a essa sujeição numa Alemanha arruinada e deixada à própria sorte. No clube noturno o cartaz indica: "permitida a entrada de mulheres de qualquer nacionalidade. Se requerem dois atestados: o político e o da ausência de doenças venéreas”. Outro, ao lado, lembra que a entrada é permitida apenas ao pessoal americano. O espancamento em sua porta indica quem é o intruso - o praça negro, não considerado como tal. A 
falsidade dos líderes e da elite político-militar-econômica é contraposta a sinceridade de soldados, como o sargento Harry Perebeynoga [Ivan Lyubeznov] e oficiais de média patente, como o capitão Tommy [Erast Garin]. A ideia de aproximação de classes populares entre americanos e soviéticos é reforçada pela ascendência ucraniana de Perebeynoga.

Em Sekretnaya missiya, o piloto americano prisioneiro de guerra, que prefere a morte a participar como intermediário dos encontros, é salvo pela agente soviética. Na festa da vitória, em Nova York, enquanto os agentes e senadores conspiram, os cartazes da população pedem paz. Na Inglaterra, sob a janela de Churchill, a população inglesa leva faixas escritas com "longa vida a Stalin" e um marinheiro brada o mesmo. A festa na Times Square ou sob a cúpula de São Paulo e a Abadia de Westminster se congraça no corte subsequente, que leva aos festejos populares na Praça Vermelha - o povo é o mesmo em qualquer lugar, as fronteiras pouco importam para o espírito do proletariado, por mais que esteja afastado por seus governantes.

O diretor Mikheil Chiaureli, conterrâneo de Stalin, copia a técnica que Leni Riefenstahl utilizou para divinizar a imagem de Hitler em $O$ trinfo da vontade, 1935, ou ao menos exibir o líder alemão como guia legítimo de toda a nação. Como Hitler, Stalin chega a Berlim num avião prateado, reluzente entre as nuvens. As massas se espremem para saudar sua chegada, num verdadeiro frenesi digno da importância de seu personagem. Não são apenas os vitoriosos soldados soviéticos os que estão presentes. Há uma multidão de várias nações inclusive prisioneiros recém-libertados e soldados anglo-americanos, saudando Stalin em Berlim, em Padenie Berlina, 1950. Mas, ao contrário da narrativa construída por Chiaureli, Stalin nunca esteve em Berlim, mas sim em Potsdam, e não nas horas imediatamente posteriores à captura do Reichstag, mas sim quase dois meses depois, entre 17 de julho e 2 de agosto, para a conferência com Harry Truman e Clement Attlee, e, por fim, não se apresentara em um Douglas DC-3 ou na imitação soviética Lisunov Li-2, mas sim num trem blindado. Seu único voo fora para a Conferência de Teerã, em 1943. Stalin temia aviões. E a lembrança de acidentes e ataques como os que vitimaram o general Sikorski e o almirante Yamamoto estava fresca na memória. Rosenstone acudiria para a compressão e economia do tempo, necessidades naturais da linguagem fílmica. O uso político dessas técnicas, transformando Stalin no real clímax da derrota do nazismo e no 
Revista Brasileira de História \& Ciências Sociais - RBHCS

Vol. $12 \mathrm{~N}^{\circ} 23$, Janeiro - Junho de 2020

líder das massas de todo o mundo - mesmo aquelas que formam a base dos rivais da emergente Guerra Fria.

\section{Cultura}

A cultura americana em geral fora vista pelos soviéticos como inferior, como o próprio Gorbachev (1988) deixa claro. O mesmo não ocorre com a da Europa Ocidental, em especial a britânica. Não poucos filmes soviéticos eram adaptações das obras de Willian Shakespeare, Daniel Defoe e Arthur Conan Doyle realizados ainda nos anos de Stalin. Os americanos incomodavam o regime stalinista em um âmbito: o musical, de grande atratividade para jovens urbanos e a intelligentsia ocidentalizadora. A música introdutória de Aram Khachaturian para Russkiy vopros acentua a disparidade social apresentada nas imagens, o tom frenético e agressivo, baseando-se na música orquestral de filmes americanos da época. Posteriormente, introduz uma trilha baseada no antecessor do Jazz, o Ragtime - talvez pela pressão contrária ao Jazz e ao cerco aos seus defensores dentro da URSS. Algumas passagens parecem se referir ao trabalho de George Gershwin (1898-1937) com o Blues, obras que o maestro armênio certamente conhecia. Alexandrov, um dos defensores do Jazz na década de 1920, em filmes como Vesolyye rebyata [Amigos felizes], 1934, em Vstrecha na Elbe apresenta o ritmo como selvagem, um complemento para o linchamento racial. Em Proshchay, Ameryka! a música americana é tola. É exibido um grupo civilmilitar que lembra uma mistura dos grupos vocais e da big band americanos em especial ao gênero misturado ao jazz criado por Glenn Miller e sua orquestra. Em Smeliie lyudi [Pessoas ousadas], 1950, de Konstantin Yudin, o que os nazistas ouvem na cidade soviética ocupada não são canções de bares e marchinhas, mas sim Jazz, relacionando os antigos inimigos aos novos. Até mesmo animações do pós-guerra apresentavam os perigos dos imitadores dos americanos, e um aviso para as consequências. Nesse período e temática musical, a distinção entre classes dominantes e trabalhadoras desaparece. Em Russkiy vopros a dissolução dos costumes soviéticos e a retórica da comunidade das mulheres (escolhida pelo diretor soviético ante a outra retórica possível, da dessexualização da sociedade como fenômeno necessário da desindividualização MEHNET, 1966) é substituída pela frivolidade do sexo entre os americanos (caso do protagonista e sua garota 
Revista Brasileira de História \& Ciências Sociais - RBHCS

Vol. $12 \mathrm{~N}^{\circ} 23$, Janeiro - Junho de 2020

ou da revista entre os funcionários da emissora de rádio). Ainda assim distinguese o comportamento das elites: os ingleses, aristocratas falsos. Os americanos, brutamontes broncos com o desejo de adquirir ares aristocráticos.

\section{Um sistema autoritário e a falácia da democracia liberal e da liberdade de imprensa}

O filme mais contundente na crítica ao sistema americano é Russkiy vopros, de 1947. O filme se inicia em abril e 1946 e segue a trajetória de um jornalista integro, Harry Smith [Vsevolod Aksyonov], durante um ano. Imagens de documentários americanos são transformados pela montagem num libelo anti-América: cenas da grandiosidade e verticalidade de Nova York, em um filme americano, dariam lugar a locais como a $5^{\mathrm{a}}$ Avenida, o Rockfeller Center, East Side. Mikhail Romm usa cenas em que a câmera vai do céu retalhado pelos prédios (imagem com a qual os próprios soviéticos acostumavam-se com o projeto de construção de sete arranha-céus em Moscou entre 1947-53, as Sete irmãs, que na época eram os prédios mais altos do continente europeu, com o maior deles sediando o campus principal da Universidade de Moscou) em direção aos minúsculos seres humanos. A imagem que se segue (um corte rápido da aproximação leva a locais que não eram aqueles da cena da aproximação da câmera - uma rua comercial) é a dos bairros pobres dos anos 1940, Brooklyn, Harlem, Queens, Bronx, como se por entre o fausto da imensa superfície se escondesse a degradação e decadência capitalistas. Cenas de riqueza e ociosidade e pobreza e trabalho se alternam (trabalho com montagem que marcaria o diretor ainda nos anos 1960 com seu Fascismo ordinário) como imagens de uma década antes, com as grandes filas da sopa da Grande Depressão (prática adotada também pelo cinema americano). A liberdade é uma falácia, cerceada pela repressão policial (entram, mais uma vez, imagens da Estátua da Liberdade). A pobreza da população negra é contraposta a opulência do Empire State. O sistema econômico é irracional, com as imagens de grãos e leite sendo jogados fora (mais uma imagem da Grande Depressão dada como a imagem do desperdício natural do sistema). Como muitos filmes americanos, o diretor faz questão de ressaltar o mundo de uns e o mundo de outros, a retórica e a prática concreta do regime. $\mathrm{O}$ que manteria tal caos superficialmente coeso e pacificado? $\mathrm{O}$ diretor insere 
imagens das grandes prensas, milhares de jornais sendo embarcados em caminhões e distribuídos - chegando até mesmo aos trabalhadores em uma obra.

Chiaurelli usa personagens para sugerir estruturas. Mikhail Romm sempre deixa as estruturas perceptivas: alguém sempre tomará o lugar daquele que se recusar a seguir as normas sociais e econômicas que regem o país e a imprensa. Um repórter se tivesse o mesmo dinheiro que o dono da rede de jornais Mcperson [Mikhail Astangov], seria tão indecente quanto o mesmo. Dois repórteres se queixam de manipular o noticiário, mas sabem que se não o fizerem, serão demitidos e o noticiário será alterado da mesma maneira. Omitir opinião diferente é condenar-se ao desemprego, ao ostracismo, à destruição familiar (especialmente de sua renda). Nada está em suas mãos, mas sim nas do editor, que, por sua vez, apenas segue os tubarões de Wall Street e é tão substituível quanto os mesmos. Nada gera comoção. Tudo é normal, sistêmico. A autocensura e propaganda são percebidas como comportamentos básicos da burguesia para o controle de sua população e acesso ao poder político-econômico. Ao contrário, como o protagonista e um dos jornalistas de menor renda e mais apreciado para a elaboração de noticiário falso (dinheiro de jornalistas soviéticos para fomentar greves e sindicatos) afirmam, os jornalistas soviéticos dizem a verdade (ao contrário dos americanos). Há autoridade em sua fala, pois os conheceram pessoalmente no Elba. Não existe qualquer sugestão de que as mesmas pressões ocorram na URSS, com a substituição de Wall Street pelo Kremlin e a burguesia pela burocracia soviética. Exibe-se o trabalho das redações:

Mcperson - Olá, Bill.

Bill Preston - Olá, chefe.

Mcperson - Alguma novidade sobre a Rússia hoje?

Bill Preston - A United Press publicou 50 linhas sobre "Russos em Viena”, pelo Harner. Elogia os russos. Publicamos?

Mcperson - Claro, sou objetivo, não sou o Hearst. Coloque na página dezesseis. O que mais?

Bill Preston - Whipman. Russos e dominação mundial.

Mcperson - Antes da página cinco. O que mais?

Bill Preston - Propaganda italiana sobre pilotos russos na Eritréia. É um absurdo descarado.

Mcperson - Primeira página, título sensacionalista.

Bill Preston - Os russos refutarão amanhã mesmo.

Mcperson - Tudo bem, vamos colocar na página vinte. Todos lerão o artigo, poucos lerão a réplica [...].

Bill Preston - Isso não é muito agradável. Até um carro deve parar antes de dar marcha ré.

Mcperson - O quê? Não entendi. 
Bill Preston - Estamos sendo muito agressivos.

Mcperson - Sim, estamos muito agressivos.

Bill Preston - Você mudou muito, chefe.

Mcperson - Mudei... Aconselho que faça o mesmo (RUSSKIY,... 1947).

E a coação presencial feita pelo empresário das comunicações ao seu escritor best seller:

Mcperson - Muito bem. Você provavelmente está conformado em perder sua casa, seu carro e seu trabalho no meu jornal. Devo decepcioná-lo, pois isso será só o começo. Você não trabalhará nunca mais. Eu vou cuidar disso. Mas isso não é tudo. Encontraremos dez americanos que irão jurar por bons dólares americanos que você é um agente de Moscou, e que eles viram como você recebeu dinheiro pelo seu livro. Todos os meus 38 jornais estarão falando de você. O comitê do Senado irá investigálo. Vai ter que abdicar da sua vida. Sabe o que isso significa? Quando você estiver completamente quebrado, sua esposa ainda vai deixar você.

Gould - Ela é mais inteligente. Vai embora antes.

Mcperson - Ficou claro? [...].

Harry Smith - Sim, entendi.

Mcperson - Que bom. Agora, você pode evitar tudo isso reescrevendo seu livro em 10 dias.

Harry Smith - Não vou reescrever.

Mcperson - Entendi. Imaginei que seria difícil para você fazê-lo. Então achei alguém que o fará. Vai lhe custar uns 2 ou 3 mil dólares.

Harry Smith - O que é isso?

Mcperson - Sua autorização para permitir qualquer alteração no livro. Assine.

Harry Smith - Não vou assinar.

Mcperson - Pense bem.

Harry Smith - Já pensei.

Mcperson - Pense mais uma vez.

Harry Smith - Não.

Mcperson - Tudo bem. Você vai passar por maus bocados, maus mesmo. E quando estiver na pior, sem nada nem para comer, você pode voltar ao meu jornal e trabalhar para mim. É claro que não será um editor ou correspondente, ou repórter... Nem mesmo um redator. Vou colocá-lo... para trabalhar na editoria policial, 10 horas por dia na delegacia, a 35 dólares por semana. 8 linhas sobre assaltos, 6 sobre incêndios, ou vice-versa. Não é tão ruim. Eu mesmo comecei assim. Adeus, Harry. Tenha uma boa viagem. Não esqueça. Vou ajudá-lo quando estiver na pior. Você vai trabalhar para mim como repórter policial! Vai trabalhar como repórter policial! (RUSSKIY,... 1947).

O trabalhador americano é servo da propaganda terceirizada - ao repetir motes anticomunistas sobre a comunidade das mulheres ou a coletivização de bicicletas, e de ter sua temperatura checada para ter certeza que não delira, o 
protagonista pergunta: "sua propaganda ou minha?” - do jornal onde trabalha. Os jornais não servem apenas para o controle mental, mas também server a finalidade propriamente capitalista do lucro, por meio do sensacionalismo, imprensa marrom, etc. Dois jornais são citados: o do famoso William Randolph Hearst e o de McPerson. Isso, no entanto, não significa opiniões diferentes, informação verdadeira, liberdade de imprensa. Ambos os jornais disputam o mesmo material anticomunista. McPerson coage a editora que pretendia publicar o livro de Smith (não por amor à verdade, mas sim as estimativas de um lucro de 100 mil com o escândalo). O diretor não permite dubiedade no filme, que pudesse sugerir coações também na URSS, como a que levaria Dovjenko a filmar uma película de propaganda, ou a própria inexistência de editoras realmente autônomas na URSS que pudessem cogitar imprimir samizdat - apenas acentua que tal noção de liberdade não existe de fato sequer nos EUA). Os personagens fornecem a tradicional visão soviética (não apenas soviética, mas dentro desses parâmetros, sim) dual do mundo americano cindido entre liberais (com os quais se pode negociar e que estariam aptos a aceitar o mundo concreto) e conservadores (falsificadores da história, da realidade, incontornáveis e impossíveis de se conciliar):

Mcperson - Foi sua ideia, foi você que me recomendou a usar Smith, maldição!

Gould - Eu lhe falei que ele era um liberal desde o começo!

Mcperson - O que você me disse?

Gould - Para impor condições rigorosas!

Mcperson - Por que deu ouvidos a ele?

Gould - Fazer propaganda sem ler o livro! Droga! (RUSSKIY,... 1947).

Mesmo a pequena e descapitalizada imprensa de esquerda dentro dos EUA, com a qual Smith pretende angariar alguma renda e quitar suas dívidas emergenciais, não representaria uma liberdade de imprensa real:

Harry Smith - Pegarei dez partes do meu livro e reescrevê-las como artigos.

Fred Williams - Certo.

Harry Smith - Pode publicá-los em seu jornal, eles serão populares entre seus leitores [...].

Fred Williams - Harry, você tem lido meu jornal ultimamente?

Harry Smith - Raramente.

Fred Williams - Que pena. Ouviu falar da perseguição que estou sofrendo? 
Harry Smith - Um pouco, algumas bobagens sobre o dinheiro de Moscou.

Fred Williams - Essa bobagem quase me custou o jornal. No decorrer de três dias me tornei um comunista, um americano ruim e um agente remunerado de Moscou que publica com dinheiro russo. Tudo por causa do artigo sobre a democracia na Bulgária e na Iugoslávia [...]. Estava no limite do desastre. E agora... Qualquer coisa sobre os Bálcãs ou a Rússia, eu sou forçado... como posso dizer... a ser cauteloso. Mesmo isso os deixa furiosos[...]. Harry, eu posso te dar trabalho, mas sob um pseudônimo, e sem escrever sobre a Rússia (RUSSKIY,... 1947).

O jornalista Bob Murphy [Boris Tenin] prefere arriscar a vida numa matéria em um avião a jato, rompendo barreiras de altitude, a continuar sua vida de mentiras (se levarmos em conta Youngblood e sua percepção de que durante os anos 1930-50 os diretores procuraram o escapismo dos gêneros musicais, comédias, fantasias, folclore e do novo tipo de herói das cinebiografias de cientistas, escritores, geólogos e aventureiros, o diretor poderia estar se referindo ao próprio sistema soviético. No entanto, não sobram muitos espaços para a dubiedade, como em filmes do pré-guerra). Mas ao contrário de qualquer redação soviética, sua vida foi interrompida pela busca do lucro: o repórter e o piloto desejavam um cachê maior pago pela emissora com o rompimento do recorde de altitude e a emissora, por sua vez, com o valor que obteria com a transmissão ao vivo do feito. A burguesia não seria movida apenas pelo lucro, mas também pelo poder político, como o diálogo entre MacPherson e seu editor Gould [Mikhail Nazvanov] ilustra:

Gould - Voto numa guerra preventiva e imediata contra o comunismo. Os alemães cometeram um só erro, eles se consideravam uma raça superior. Mas essa raça somos nós, os anglo-saxões. Finalmente, 50 ou 100 bombas atômicas, e não haveria mais nem Moscou, nem Leningrado, nem 15 milhões de pessoas, das quais pelo menos dois milhões são comunistas. Não seria nada mal.

Mcperson - Temo que agora uma guerra não seria muito popular, meu caro.

Gould - É nossa obrigação torná-la popular. Com um pequeno esforço, pode-se convencer qualquer um de qualquer coisa.

Mcperson - Bem, você está com um pouco de pressa.

Gould - Não é minha ideia, é do nosso amigo de Berlim. E ele estava certo.

Mcperson - Ele também estava com pressa (RUSSKIY,... 1947).

Cortes sucessivos mostram ao espectador o espanto e incredulidade de McPerson ao examinar previamente o material do jornalista antes de sua 
publicação: a pose confortável dá espaço a um tronco e cabeça lançados sobre o manuscrito, em seguida, para os óculos sobre a testa, e a passagem compulsiva de páginas. $\mathrm{O}$ diálogo entre editor e jornalista poderia ocorrer num escritório soviético:

Harry Smith - Escrevi a verdade, entendeu? Está nervoso? Sou a causa de seus problemas?

Gould - Meus problemas não são nada. É melhor pensar em si mesmo antes que seja tarde demais.

Harry Smith - É tarde demais.

Gould - Não, não é. Não sei o que escreveu, mas sei por experiência que pode transformar qualquer livro em 10 dias. Vou convencer o chefe e ele vai aceitar.

Harry Smith - Ele sim, eu não.

Gould - Não seja idiota.

Harry Smith - Talvez seja melhor irmos ao bar?

Gould - Estou falando a você como amigo.

Harry Smith - Não, você simplesmente não quer arruinar sua reputação. Você convenceu o chefe a me transformar em um canalha, então certamente eu tenho que ser um canalha. E não vou ser. Vocês falam que são inimigos da Rússia, mas isso é apenas parte da verdade.

Gould - E a outra parte, qual é?

Harry Smith - Vocês são realmente... os inimigos da América (RUSSKIY,... 1947).

O diretor consegue formular um bom prognóstico para o aparecimento do Mcarthismo. Não por astrologia ou horóscopo, mas pelo reconhecimento de que o ambiente cultural se fechava em ambas as superpotências, ou, talvez, uma conceituação tão apropriada quanto, nos impérios rivais. O império na América e o império na Eurásia precisavam galvanizar seus súditos, e a cultura era uma arma valorizada por suas respectivas elites. Um novo diálogo revelador ocorre entre o editor Kessler [Sergey Antimonov] e Smith:

Bill Preston - Escuta, Harry, eu edito as notícias estrangeiras no jornal da imprensa marrom. Toda a roupa suja do mundo passa todos os dias pelas minhas mãos. Não seja ingênuo, Harry. A América está fazendo políticas em grande escala. Precisamos da Europa, dos Bálcãs, do Extremo Oriente, do Oriente, de todos os mares, de todos os vales e rios, de todas as ilhas e penínsulas, das avenidas e ruas de todo o mundo. Precisamos de uma guerra, e para termos uma guerra precisamos de uma Rússia má. O que você lê agora em 1946 é brincadeira em comparação com o que vai ler daqui um ano ou dois. Vai achar que o fantasma de Goebbels é quem está editando. Hoje eles o jogam na rua, em um ano estarão colocando pessoas como você na prisão. Vá ver MacPherson, peça desculpas, refaça o livro, pegue o dinheiro e vá 
para casa. Mantenha-se calado como um rato e será feliz. E me deixe ir, estou realmente atrasado.

Harry Smith - Roosevelt morreu na hora errada.

Bill Preston - E mesmo? Eu não concordo. Ele morreu na hora certa.

Harry Smith - Não entendo.

Bill Preston - Sempre fico muito surpreso que políticos progressistas e poderosos morram exatamente nos momentos convenientes para a oposição.

Harry Smith - Você está louco?

Bill Preston - Acho que não.

Harry Smith - Está dizendo...

Bill Preston - Eu não estou dizendo nada (RUSSKIY,... 1947).

Durante um congresso pacifista ${ }^{8}$, Smith se vê no tablado, cercado por uma multidão nas arquibancadas:

Harry Smith - Escrevi um livro honesto sobre a Rússia [...]. Pela $47^{\circ}$ vez, estou recitando seu conteúdo em voz alta, porque em nosso país com liberdade de expressão ninguém pode publicá-lo! Por ter escrito este livro, perdi meu em prego e fui jogado na rua! Porque estou viajando pelas cidades da América recitando o conteúdo em voz alta, no nosso país, a terra da liberdade de expressão, fui convocado para um interrogatório amanhã no Comitê de Atividades Antiamericanas! Mas nem isso vai me silenciar! Eu costumava pensar ingenuamente que havia uma só América, Mas há duas! E se não há lugar para mim na América de MacPherson e Hearst, então vou achar um lugar na América de Lincoln e Roosevelt! A América não é Wall Street! A América não são 100 milionários, não são os 200 barões da imprensa e mil jornalistas corruptos! A América é o povo, somos nós! Dizem que nossos inimigos estão no exterior, na União Soviética, mas é mentira! Os inimigos da América estão aqui, a 4 quarteirões daqui, em Wall Street! Os inimigos estão a $400 \mathrm{~km}$ daqui, em Washington, no Departamento de Defesa! Os inimigos da América são aqueles que dizem que a Rússia nos ameaça com a guerra! Mentiras! Ninguém nos ameaça com a guerra! São eles, os inimigos da América, que nos impõem a guerra! Eles dizem que nós americanos somos uma nação forte, e sim, nós americanos somos uma nação forte, forte o suficiente para estrangular... os próprios belicistas! (RUSSKIY,... 1947).

\footnotetext{
${ }^{8}$ Sua principal bandeira era o desarmamento nuclear. Movimentos pacificas ocorreram e geraram apreensões em ambos os lados da Cortina de Ferro por todo o período. Os EUA o viam como instrumentalização de massas, intelectuais e artistas por Moscou (como no filme de Chaplin Um rei em Nova York, 1957, que lhe rendeu o exílio). A Europa Ocidental foi abalada em 1983 pelas mobilizações contra a implantação no continente de mísseis nucleares americanas - E. P. Thompson foi um de seus líderes. Andrei Sakharov, além de seus contatos com a embaixada americana, foi enviado ao exílio interno por sua defesa do pacifismo. As manifestações que levaram à queda do governo Honecker e do Muro de Berlim iniciaram-se em passeatas pacifistas em Leipzig. Os soviéticos apoiavam as manifestações no Ocidente, e o Ocidente, as do bloco soviético. Internamente acusadas de enfraquecer a defesa nacional e as forças armadas, externamente aplaudidas como defensoras da soberania popular.
} 
O efeito sobre a multidão não deixaria nada a desejar ao final de Rock $I V$. Smith jamais torna-se comunista. É sempre um liberal, progressista, íntegro e quase sempre corajoso repórter que resolve escrever “a verdade” sobre a URSS, rompendo o monólito de informações da mídia conservadora e do regime, que pregavam a necessidade da guerra.

\section{Conclusão}

Se a industrialização acelerada do país realizou-se com a compra ou aquisição por espionagem de tecnologia e maquinário ocidental, se durante a Era Stalin "a limusine ZIS-ZIL era, de fato, um Buick norte-americano; os tratores de Stalingrado eram cópias de um Caterpillar; os automóveis produzidos em Górki era réplicas de um Ford" (FERREIRA, 1998, p.20), os motes da propaganda antianglo-saxônicas foram copiados de Hollywood. O modelo soviético de modernização almejava atingir e sobrepujar a indústria, técnica e ciência ocidentais, partindo da imitação de produtos e de métodos de produção, como o fordismo - presente fisicamente em Stalingrado e outros pontos do país, por meio da compra de fábricas inteiras da empresa americana, montada e vistoriada por engenheiros americanos. Com o cinema não foi diferente. A indústria cinematográfica soviética não conseguiu atingir a centralização, produtividade, eficiência, logística e localização de seu modelo hollywoodiano. O realismo socialista, apesar de se inspirar fortemente no cinema clássico de Hollywood, não conseguiu atingir o mesmo apelo popular e o mesmo nível de entretenimento. Já as mensagens sobre quem é o inimigo foram facilmente assimiladas e invertidas. Maksimka, 1953, de Vladimir Braun, possui um roteiro fortemente inspirado em Gunga Din, 1939, de George Stevens; Proshchay, Amerika! [Adeus, América!], 1951, de Alexander Dovjenko, inspira-se no roteiro de Ninotchka, 1939, de Ernst Lubitsch; Zastava $v$ gorakh [Posto avançado nas montanhas], 1953, de Konstantin Yudin, baseia-se numa mistura de Gunga Din e de A Carga da Brigada Ligeira, 1936, de Michael Curtiz.

Uma característica principal da propaganda aplicada aos filmes foi o didatismo: o regime desejava que a população fosse devidamente informada de sua versão dos acontecimentos que agitavam o mundo dos primórdios da Guerra Fria e das lutas pela emancipação colonial, que além de modificar os mapas- 
múndi anualmente, representava para a URSS possibilidades de novas relações diplomáticas e comerciais. Para tanto, a nova geopolítica das superpotências deveria se tornar maniqueísta, com a apresentação dos mocinhos - comunistas, socialistas, trabalhistas, sociais-democratas de esquerda, movimentos camponeses, baixo oficialato e soldados rasos, liberais defensores da igualdade de oportunidades, neutros ou parceiros em diversos níveis da União Soviética... o campo progressista - e dos vilões - conservadores, sociais-democratas de direita, liberais restritos à arena econômica, elite militar, burguesia e industriais do emergente complexo militar-industrial dos Estados Unidos (os partidos trabalhistas conduziram as mesmas forças na Inglaterra para posições subalternas na política inglesa - apesar de seu projeto atômico, bombardeiros estratégicos, etc., não é possível comparar ambos os desenvolvimentos nos dois impérios, um afluente e outro decadente), movimentos sociais e religiosos reacionários, arraigadamente antissoviéticos.

Dois impérios espelhados, refletindo mesmas estruturas de dominação, os mesmos medos, mesmas fraquezas. Os três impérios produziram mensagens de propaganda que encontravam ressonância no regime inimigo. E em um nível elementar, todas elas se encontram, todas revelam o mal-estar interno ao projetálo sobre os rivais. A maior diferença talvez esteja na sorte dos produtores do material fílmico do que na própria oposição liberalismo versus marxismoleninismo. Cineastas e estúdios que produziam o que desejavam as elites de seus respectivos países obtiveram sucesso econômico pessoal. Aqueles que o fizeram, mesmo com críticas muito sutis, e com boas escolhas artísticas, conquistaram também o reconhecimento de seus pares. E aqueles que entraram em choque com o regime, intencionalmente ou não, foram impedidas de trabalhar, achincalhadas na imprensa, perseguidas, ou mesmo expulsas dos Estados Unidos, como Charles Chaplin. O procedimento padrão do macarthismo americano seria o da URSS pós-Stalin. Durante seu governo, no entanto, exílio interno, prisão, morte pelas instituições legais ou encobertas, estavam nas opções de condenações. Na URSS uma condenação das diretrizes estatais que possa ser comparada a Um rei em Nova York, 1957, de Charles Chaplin, apareceria apenas em Dobro pozhalovat, ili Postoronnim vkhod vospreshchen [Bem-vindo, ou proibida a entrada], 1964, de Elem Klimov, concebido após a expulsão da múmia de Stalin do Mausoléu de Lenin, em 1962. 
Russkiy vopros exibe a visão oficial de que a democracia liberal e a liberdade de imprensa são falácias. Segundo a ótima marxista-leninista, a única e verdadeira democracia seria a ditadura do proletariado. A democracia liberal, ou burguesa, seria apenas um simulacro de democracia, ocultando a realidade de um Estado à serviço da burguesia (STALIN, 1954). Não caberia afirmar que o regime soviético copiou e reproduziu o discurso antissoviético ocidental do totalitarismo. A vida privada dos personagens não é esquadrinhada pelo Estado. Pelo contrário, autoridades públicas não aparecem. Toda a maquinaria do regime repousa nas mãos privadas da burguesia que, no entanto, segundo o cinema chancelado pelo Kremlin, revela o mesmo desempenho na lavagem cerebral da população local, por meio da propaganda intensa e falsificadora da realidade, alegada pela propaganda capitalista e atribuída a seu rival ideológico soviético. $\mathrm{O}$ povo americano, ludibriado pela máquina de propaganda da burguesia/Estado e inconscientemente preso a um sistema infernal, com consequências como o gangsterismo, não constitui uma visão intrinsicamente diferente da propalada pelos jornais e filmes estadunidense sobre a população soviética, Stalin e o NKVD. Sem dúvidas esse fenômeno de banditismo urbano não atribulou a vida americana apenas nos anos 1920 e 1930, momento de seu maior impacto. Processos contra a máfia agitaram o país nos anos 1940 e 1960. No entanto, a propaganda soviética, como a americana, adora condensar décadas distintas e generalizar ou sistematizar fenômenos datados - sempre que negativos à imagem do inimigo, enquanto naturalizam, minimizam ou omitem seus próprios problemas.

\section{Referências bibliográficas}

ALEKSIÉVITCH, Svetlana. A guerra não tem rosto de mulher. São Paulo: Companhia das Letras, 2016.

BEEVOR, Antony. A Segunda Guerra Mundial. Rio de Janeiro: Record, 2015 .

BORDWELL, David; THOMPSON, Kristin. A Arte do Cinema: uma introdução. Campinas: Unicamp, 2013

BOURDIEU, Pierre. As regras da arte. São Paulo: Cia. das Letras,1996. CHOMSKY, Noam. Novas e Velhas Ordens Mundiais. São Paulo: Scritta, 1996. 
Revista Brasileira de História \& Ciências Sociais - RBHCS

Vol. $12 \mathrm{~N}^{\circ} 23$, Janeiro - Junho de 2020

CONQUEST, Robert. Reflections on a ravaged century. Nova York:

Norton, 2000.

FERREIRA, Jorge. URSS: Mito, utopia e história. Tempo, Rio de Janeiro, Vol. $3, \mathrm{n}^{\circ} 5, \mathrm{p} .75^{-103}, 1998$.

FERRO, Marc. Cinema e história. Rio de Janeiro: Paz e Terra, 1992.

FERRO, Marc. El Cine, una visión de la historia. Madrid: Akal, 2008.

FERRO, Marc. O filme: uma contra-análise da sociedade? In: NORA, Pierre (org.). História: novos objetos. Rio de Janeiro: Francisco Alves, 1975.

FÜRST, Juliane. Late Stalinist Russia: society between reconstruction and reinvention. Londres: Routledge, 2006.

GILBERT, Martin. Winston S. Churchill: road to victory, 1941-1945, v.7. Boston: Houghton Mifflin, 1986.

GLANTZ, David; HOUSE, Jonathan. When titans clashed: how the Red Army stopped Hitler. Lawrence: University Press of Kansas, 1995.

HALLIDAY, Fred. Génesis de la Segunda Guerra Fría. Cidade do México: F.C.E., 1989.

HOBSBAWM, Eric (org.). História do Marxismo, 9: O Marxismo na época da Terceira Internacional: problemas da cultura e da ideologia. Rio de Janeiro: Paz e Terra, 1987.

JOHNSTON, Timothy. Being Soviet: identity, rumour, and everyday life under Stalin, 1939-1953. Nova York: Oxford University Press, 2011.

KENEZ, Peter. Cinema and Soviet society: from the Revolution to the death of Stalin. Londres: I.B. Tauris Publishers, 2001.

LEWIN, Moshe. O século soviético. Rio de Janeiro: Record, 2007.

MENEY, Patrick. A kleptocracia: a corrupção na União Soviética. Rio de Janeiro: Record, 1984.

MORETTIN, Eduardo Victorio. O cinema como fonte histórica na obra de Marc Ferro. História: Questões \& Debates, Curitiba, no 38, p. 11-42, 2003.

OVERY, Richard. Os ditadores. Rio de Janeiro: José Olympio, 2009.

PEREIRA, Wagner Pinheiro. O poder das imagens: cinema e política nos governos de Adolf Hitler e de Franklin D. Roosevelt. São Paulo: Alameda, 2012.

POSPELOV, P. N. Istorria Velikoi Otecestvennoi Voiny Soiuza. Moscou: Voyenizdat, 1960-65. 6v.

ROLLBERG, Peter. Historical dictionary of Russian and Soviet cinema. Lanham: Scarecrow Press, 2009.

ROSENSTONE, ROBERT. A história nos filmes, os filmes na história.

Rio de Janeiro: Paz e Terra, 2015.

SCHVARZMAN, Sheila. Marc Ferro, cinema, história e cinejornais: Histoire parallèle e a emergência do discurso do outro. ArtCultura, Uberlândia, v.15, no 26, jan.-jun., p. 187-203, 2013. 
SILVA, Francisco Carlos Teixeira da; LEÃO, Karl Schurster Souza; LAPSKY, Igor. $O$ cinema vai à guerra. Rio de Janeiro: Elsevier, 2015.

STALIN, J. V. Obras, $6^{\circ}$ vol. Rio de Janeiro: Editorial Vitória Ltda, 1954.

VOLKOGONOV, Dmitri. Stalin: triunfo e tragédia. Rio de Janeiro: Nova Fronteira, 2004.

WARD, Chris. What is History? the case of Late Stalinism. Rethinking History, v.8, $\mathrm{n}^{\mathrm{o}}$ 3, p.439-458, 2004.

WERTH, Alexander. A Rússia na Guerra. Rio de Janeiro: Civilização Brasileira, 1966.

WHITE, Hayden. Meta-história: a imaginação histórica do século XIX. São Paulo: USP, 1995.

YOUNGBLOOD, Denise. Russian war films: on the Cinema Front, 19142005. Kansas: University Press of Kansas, 2007.

\section{Fontes}

ADMIRAL Nakhimov [Almirante Nakhimov]. Direção: Vsevolod Pudovkin. Moscou: Mosfilm, 1946. 1 DVD (88 minutos), P\&B.

ADMIRAL Ushakov [Almirante Ushakov]. Direção: Mikhail Romm. Moscou: Mosfilm, 1953. 1 DVD (108 min), color.

GEROI Shipki [Os heróis de Shipka]. Direção: Sergei Vasilyev.

Leningrado/Sofia: Lenfilm/Boyana Film, 1954. 1 DVD (137 min), color.

KORABLI shturmuyut bastiony [Bastiões da tempestade dos navios/Almirante Ushakov parte II]. Direção: Mikhail Romm. Moscou: Mosfilm, 1953. 1 DVD (108 min), color.

MAKSIMKA. Direção: Vladimir Braun. Kiev: Dovjenko Kinostudiya, 1952. 1 DVD (78 min), color.

NEZABYVAEMYY 1919 god [O inesquecível ano de 1919]. Direção: Mikheil Chiaureli. Moscou: Mosfilm, 1951. 1 DVD (108 min), color.

PADENIE Berlina [A queda de Berlim]. Direção: Mikheil Chiaureli. Moscou: Mosfilm, 1950. 2 DVDs (151 min), color.

PROSHCHAY, Amerika! [Adeus, América!]. Direção: Alexander Dovjenko; Julia Solntseva. Moscou: Mosfilm, 1951. 1 DVD (70 min), color.

RUSSKIY vopros [Questão russa]. Direção: Mikhail Romm. Moscou: Mosfilm, 1947. 1 DVD (91 min), P\&B.

SEKRETNAYA missiya [Missão secreta]. Direção: Mikhail Romm. Moscou: Mosfilm, 1950. 1 DVD (98 min), P\&B.

SEREBRISTAYA pyl [Pó de prata]. Direção: Pavel Armand; Abram Room. Moscou: Mosfilm, 1953. 1 DVD (102 min), color.

SHKOLA zlosloviya [Escola de fofoca]. Direção: Abram Room. Moscou: Mosfilm, 1952. 1 DVD (161 min), P\&B. 
SMELIIE lyudi [Pessoas ousadas]. Direção: Konstantin Yudin. Moscou: Mosfilm, 1950. 1 DVD (95 min), color.

SPORTIVNAYA Chest [Honra esportiva]. Direção: Vladimir Petrov. Moscou: Mosfilm, 1951. 1 DVD (107 min), color.

SUD chesti [Tribunal de honra]. Direção: Abram Room. Moscou: Mosfilm, 1948. 1 DVD (90 min), P\&B.

V mirnyye dni [Em dias de paz]. Direção: Vladimir Braun. Kiev: Kievskaya Kinostudiya, 1950. 1 DVD (97 min), color.

VELIKAYA sila [Grande poder]. Direção: Friedrich Ermler. Leningrado:

Lenfilm, 1950. 1 DVD (106 min), P\&B.

VELIKIY perelom [A grande virada]. Direção: Fridrikh Ermler. Leningrado: Lenfim, 1945. 1 DVD (108 min), P\&B.

VELIKIY voin Albanii Skanderbeg [Scanderbeg, grande guerreiro da Albânia]. Direção: Sergei Yutkevich. Tirana/Moscou: Albfilm/Mosfilm, 1953. 1 DVD (120 min), color.

VSTRECHA na Elbe [Encontro no Elba]. Direção: Grigori Aleksandrov. Moscou: Mosfilm, 1949. 1 DVD (104 min), P\&B.

ZAGOVOR obrechennyh [Conspiração dos condenados]. Direção: Mikhail Kalatozov. Moscou: Mosfilm, 1950. 1 DVD (103 min), color.

ZASTAVA v gorakh [Posto avançado nas montanhas]. Direção: Konstantin Yudin. Moscou: Mosfilm, 1953. 1 DVD (100 min), color. 


\section{Anexos}

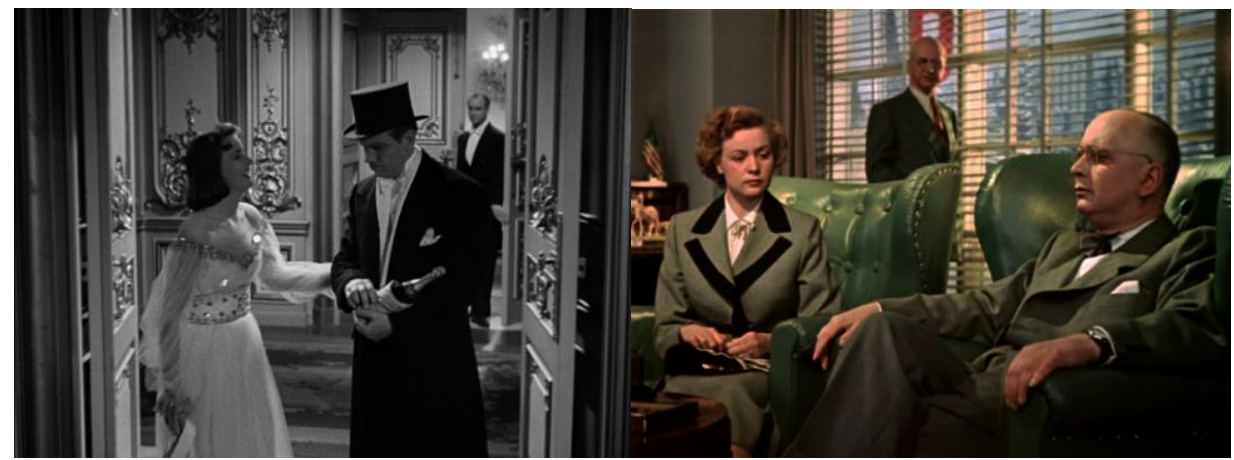

Figura 1. Ninotchka e Proshchay, Amerika! Duas protagonistas adeptas de seus respectivos regimes que decidem abandoná-los pelo rival. NINOTCHKA, 1939; PROSHCHAY..., 1951.

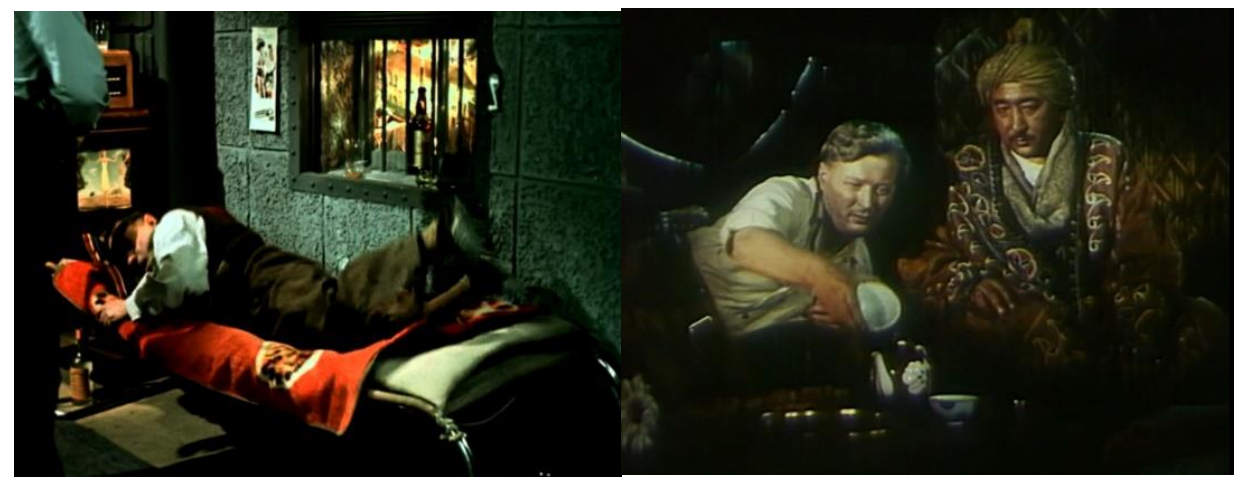

Figura 2. Anglo-americanos como bêbados: o departamento de comunicações e escutas na embaixada americana; o espião americano disfarçado de arqueólogo entre os bandidos da Ásia Central muçulmana soviética. PROSHCHAY..., 1951; ZASTAVA..., 1953.

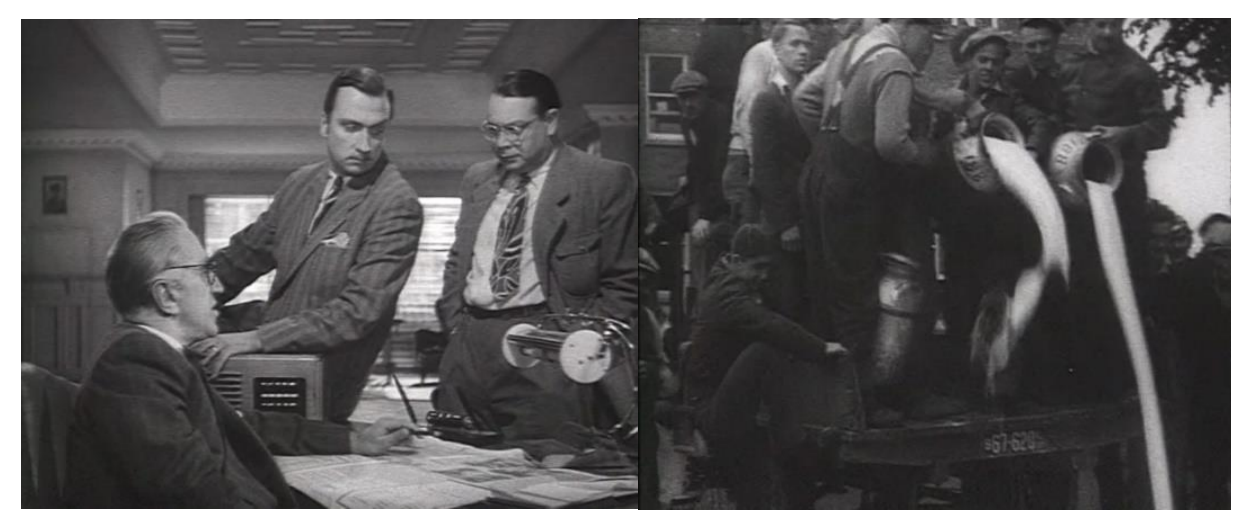

Figura 3. O inimigo americano: autoritarismo, cooptação (com Preston sendo coagido no escritório), desperdício e irracionalidade econômica (com imagens da Grande Depressão que já possuíam 14 anos quando Romm as utilizou). RUSSKIY..., 1947. 

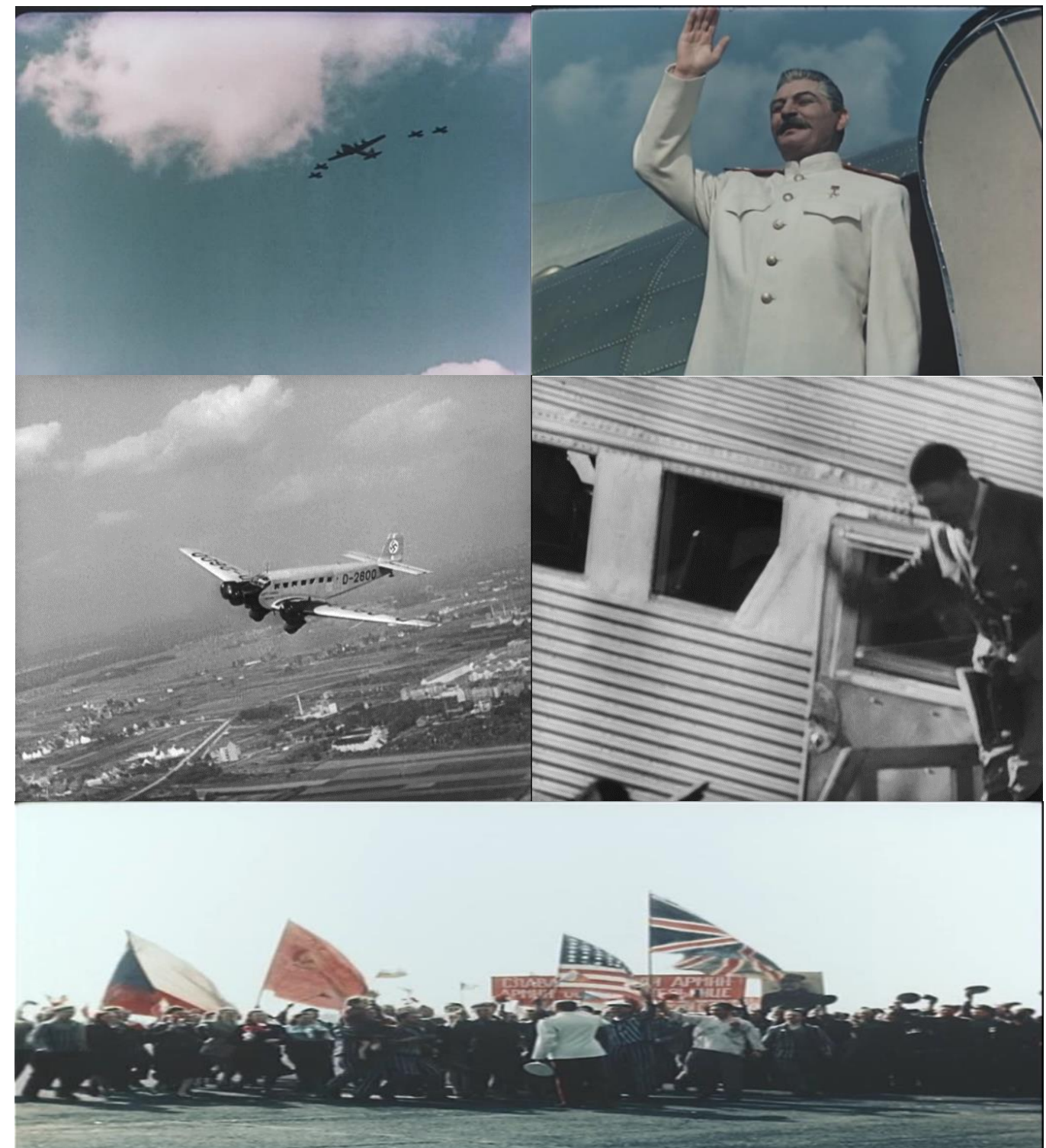

Figura 4. O líder vindo dos céus: Hitler, que realmente se deslocou de avião para Nuremberg, e Stalin, que fora até Potsdam de trem blindado e com escolta terrestre ao longo da via férrea. Chiaureli pôs Stalin descendo dos céus para imitar Riefenstahl e o sucesso da propaganda nazi em enaltecer a imagem do Führer, agora à serviço da do batiuchka ou vojd? Revela a adesão do diretor ou sua verdadeira opinião sobre o líder? Ou ainda uma pragmática cópia de linguagem? Talvez a maior diferença esteja na recepção do ditador: por massas de diversas nações, populares, simples, eufóricas, mas sem organização, e os seguidores do partido nazi em Nuremberg, com uniformes vistosos ou alinhados em camisas marrons, perfilados, em transe, mas mantendo o aspecto grave e a formação. O internacionalismo e o nacionalismo. PADENIE..., 1950; Triunfo da Vontade, 1935 . 